Криворізький педагогічний інститут ДВНЗ «Криворізький начіональний університет»

\title{
КОНЦЕПТУАЛЬНІ ОСНОВИ ФОРМУВАННЯ РЕФЛЕКСИВНИХ УМІНЬ СТУ ДЕНТІВ ПЕДАГОГІЧНОГО УНІВЕРСИТЕТУ У ПРОЦЕСІ САМОСТІЙНОЇ НАВЧАЛЬНОЇ ДІЯЛЬНОСТІ
}

У статті висвітлено проблему концептуальних основ формування рефлексивних умінь студентів педагогічного університету у прочесі самостійної навчальної діяльності.

Ключові слова: рефлексія, уміння, рефлексивні уміння, самостійна навчальна діяльність студентів.

В статье освещена проблема конщептуальних основ формирования рефлексивных умений студентов педагогического университета в проиессе самостоятельной учебной деятельности.

Ключевые слова: рефлексия, умения, рефлексивные умения, самостоятельная учебная деятельность.

The article illustrates the problem of the basic concepts of forming students' reflexive abilities in Pedagogical University in the process of self-directed (independent) educational activity.

Key words: reflection, abilities, reflexive abilities, self-directed (independent) educational activity.

Трансформаційні процеси в освіті актуалізують проблему вдосконалення самостійної навчальної діяльності студентів педагогічних університетів. Головним результатом навчання має стати орієнтація навчального процесу на студента, створення умов для формування творчої ініціативи та педагогічної самостійності. Нагальне завдання, яке важливо розв'язувати - навчити студента вчитися, самостійно набувати знання, а після закінчення навчання - розвивати індивідуальні якості, властиві творчому педагогу, упродовж усього життя.

Саме цим зумовлено актуальність постановки проблеми визначення концептуальних основ формування рефлексивних умінь студентів педагогічного університету у процесі самостійної навчальної діяльності.

У теорії та практиці вищої освіти розглянуто дидактичні основи активізації самостійної навчальної діяльності студентів (В. Буряк, О. Малихін, М. Скаткін, Т. Шамова, 
Г. Щукіна); здійснено аналіз основ підвищення ефективності навчання (А. Алексюк, О. Пєхота, В. Семиченко); проведено дослідження впливів самостійної роботи на процес пізнання (В. Буряк, В. Вергасов, Б. Ссипов); зроблено порівняльний аналіз організації самостійної пізнавальної діяльності (Т. Кошманова, М. Лещенко); висвітлено формування рефлексії педагогів (Н. Алексєєв, А. Бизяєва, Т. Ільїна, Т. Яловець). Велике значення під час вивчення питання рефлексивних умінь мають дослідження про підготовку педагога в системі вищої освіти, розглянуті в роботах О. Вербицького, Б. Гершунського, Ю. Смельянова, О. Малихіна, А. Маркової, Ю. Сенько, В. Сластьоніна. Аналіз наукових джерел засвідчує, що дослідження особливостей рефлексії ведеться на теоретичному, методичному та практичному рівнях. Разом з тим у педагогіці відсутні наукові праці, у яких обгрунтовувано б методологічні та загальнотеоретичні аспекти формування в студентів педагогічних університетів рефлексивних умінь самостійної навчальної діяльності.

Відповідно до цього, мета сmammi - проаналізувати принципово важливі питання щодо визначення концептуальних основ формування рефлексивних умінь студентів педагогічного університету у процесі самостійної навчальної діяльності: 1) питання рефлексивної позиції студента; 2) методи навчання рефлексії 3) педагогічні умови розвитку рефлексії.

Навчання у виші, на жаль, не забезпечує цілеспрямованого формування необхідних рефлексивних умінь майбутніх педагогів, які є важливими щодо покращення процесу самостійної навчальної діяльності під час перебування у вищій педагогічній школі, а також для подальшої професійнопедагогічної діяльності.

Формування рефлексивних умінь, на наше переконання, $\epsilon$ тісно пов'язаним із формуванням рефлексивної позиції студента.

Рефлексивна позиція студента, на думку А. Маркової [5] та Г. Щедровицького [9], формується за умови, якщо в навчанні студент має справу зі змістом освіти як відкритою системою, яка передбачає досвід творчої діяльності.

Цікавим є підхід П. Решетникова, який розкриває специфіку формування професійної рефлексії в студентів, якщо вони в зовнішньому плані бачать зразки аналізу, оцінки діяльності, самі включаються у процес, беруть участь у діагностиці своїх якостей [8]. 
В. Болотов, С. Ісаєв, В. Слободчиков, Н. Шайденко вважають, що ефективною формою засвоєння рефлексії $\epsilon$ поточна рефлексія, здійснювана в ході навчального процесу за типом «човника», і підсумкова рефлексія, що завершує логічно або тематично замкнутий період діяльності [1].

В. Метаєва пропонує шляхи професійної підготовки студента за допомогою оволодіння технікою рефлексації самостійної навчально-пізнавальної та професійної педагогічної діяльності [6].

Відсутність розроблених педагогічних підходів до формування рефлексивних умінь у межах навчального процесу призводить до того, що у практиці вишівського навчання формування в студентів рефлексивних умінь здійснюється переважно емпірично, тобто без необхідного наукового обгрунтування.

Самостійна пізнавальна діяльність студентів розглядається нами як діяльність, що передбачає самодетермінованість, самомотивованість, самопрограмованість пізнавальної діяльності студентів, реалізується у вигляді системи самостійних пізнавальних дій і зумовлена рівнем розвитку їх пізнавальних процесів та емоційно-вольової сфери.

На думку науковця О. Малихіна, розуміння суті самостійної навчальної діяльності, терміна «організація» надає можливість сформулювати визначення поняття «організація самостійної навчальної діяльності студентів»: «це - система спільних дій викладача і студента, спрямована на реалізацію пізнавального циклу кожного студента, у процесі якого активну детермінуючу роль виконують студенти» [3].

Для розуміння своєї діяльності студент повинен перейти на рефлексивну позицію щодо досвіду своєї життєдіяльності. Цей вихід, на думку дослідників Є. Ісаєва та В. Слободчикова, можна здійснювати за допомогою усвідомлення свого незнання цілей, мотивів, результату й засобів його досягнення, що є вихідною умовою для становлення й розвитку вільної діяльнісної особистості педагога. Для цього кожному студенту - майбутньому педагогу - необхідно самому ставити цілі, програмувати власну діяльність й аналізувати результати. Студент самостійно вибудовує програму власних дій за таким алгоритмом:

- уявляє картину майбутнього - обставини й себе (обставини задаються іншими, їх намірами, станами, стосунками); 
- визначає, яка для цього повинна бути його діяльність;

- оформлює план найближчих дій і здійснює ці дії, ураховуючи, що в ситуації є інші люди [1].

Рефлексія - комплексна розумова здатність до постійного аналізу й оцінки кроків індивідуальної діяльності. Кожному 3 аспектів рефлексії властиві вміння: особистісного (адекватне самосприйняття, уміння визначати й аналізувати причини своєї поведінки, порівняння з минулим і прогнозування перспектив розвитку); комунікативного (розуміння причин дій іншого суб'єкта у процесі взаємодії); інтелектуального (визначення підстави діяльності, уміння прогнозувати подальший хід дій та оцінювати правильність обраних методів плану).

Т. Разіна вказує, що на нині існує низка методів навчання рефлексії: створення на робочому місці студента рефлексивного середовища (С. Степанов), використання різного роду ігор, об'єднаних у навчальні сесії (О. Анісімов, Г. Щедровицький), культивування механізмів особистісної та інтелектуальної рефлексії в ситуації лабораторного експерименту, шляхом розв'язання нестандартних, творчих завдань (В. Зарецький, І. Семенов) [7].

Для розвитку рефлексії важливим є визначення педагогічних умов.

Першою педагогічною умовою розвитку рефлексії є спеціально організована рефлексивна діяльність, яка характеризується таким: їй притаманні властивості діяльності (цілеспрямованість, перетворювальний характер, наочність, усвідомленість) і характерна спільність у побудові способів процесу діяльності та кінцевих результатів.

Другою педагогічною умовою розвитку рефлексії $є$ наявність рефлексивного середовища. Рефлексивне середовище це певна система умов розвитку особистості. Функція середовища полягає у сприянні виникненню в особистості потреби в рефлексії.

Третьою педагогічною умовою $є$ активізація міжсуб'єктних відносин між учасниками рефлексивної діяльності. Особливість відносин у педагогічному процесі в умовах рефлексивної діяльності припускає, що викладач і студент $\epsilon$ суб'єктами діяльності, зберігаючи своєрідність своїх дій. Рефлексія становить сутнісну характеристику міжсуб'єктних відносин, оскільки здатна бути механізмом пізнання не лише своєї, але й чужої свідомості. 
Четвертою педагогічною умовою розвитку рефлексії $\epsilon$ актуалізація рефлексивності педагога. Актуалізувати рефлексивність педагога - означає аналізувати актуалізацію потреби у перегляді власної професійної позиції.

П’ятою педагогічною умовою розвитку рефлексії $є$ використання освітніх програм розвитку професійної рефлексії.

Рефлексія має суб'єктивну природу й iї становлення у процесі самостійної навчальної діяльності студентів педагогічного університету передбачає формування сукупності рефлексивних умінь. У зв'язку з цим зміст, методи і форми підготовки педагога на стадії його вишівської освіти спрямовуються на підвищення ступеня самостійності.

На думку I. Вачкова, формування рефлексивних вмінь може здійснюватися під час комунікацій, у спільній діяльності, в імітаційних і організаційно діяльнісних іграх, під час проведення психологічних тренінгів, колективного розв'язання завдань, стосунках в організаційних системах [2]. Проте, ці підходи не завжди дозволяють перенести сформовані рефлексивні вміння 3 ситуації навчання на ситуацію практичної діяльності, вони є досить складними.

Отже, як концептуальні основи формування рефлексивних умінь студентів педагогічного університету ми розглядаємо такі положення:

По-перше, процес підготовки майбутніх педагогів повинен здійснюватися на основі компетентнісно-діяльнісного підходу.

По-друге, основою процесу підготовки майбутніх педагогів повинна стати спеціально організована педагогічна рефлексія.

По-третє, необхідно гармонізувати використання компетентнісно-діяльнісного та рефлексивно-діяльнісного підходів.

По-четверте, процес формування рефлексивних умінь повинен бути адекватний природі рефлексивної дії.

Ці положення знайшли своє застосування в концептуальній моделі формування рефлексивних умінь майбутніх педагогів. Характерною особливістю моделі $є$ така організація освітнього процесу, що сприяє рефлексивній дії студентів. Для цього організовуються такі етапи:

- створення труднощів у самостійній навчальній діяльності майбутнього педагога; 
- компетенністний аналіз i реконструкція виникаючих труднощів;

- пошук причини труднощів (критерійна проблематизація) або пояснення, чому так відбулося;

- організація перенормування дії;

- демонстрація покращеної дії та іiї оцінка.

На основі цих дій рефлексії студенти не просто набувають знання у процесі самостійної навчальної діяльності, а вчаться використовувати їх безпосередньо в своїй діяльності.

Отже, викладач не лише передбачає отримання студентом нової інформації у процесі самостійної навчальної діяльності, він створює та досліджує ситуації взаємодії між студентами, планує з кожним студентом самостійну навчальну діяльність, організовує комунікацію. У студента можуть формуватися рефлексивні вміння лише у процесі активної діяльності в конкретній ситуації з усвідомленням результатів власної діяльності (чому навчився, чого не вистачає, чого ще треба навчитися).

Для нашого дослідження актуальним є розроблення системно-миследіяльнісних та особистісно-творчих шляхів формування рефлексивних умінь. Системно-миследіяльнісна методологія розглядає рефлексію як метод мислення, як спосіб одержання суб'єктом знань на підставі власної діяльності. При цьому суб'єкт «вивільняється» 3 процесу діяльності, i «виходить» на зовнішню позицію по відношенню до діяльності. Це стало принциповою відмінністю розуміння рефлексії за допомогою категорії «рефлексивний вихід». Системномиследіяльнісна теорія 3 формування рефлексивних умінь визначає необхідність постійної організації рефлексивного виходу й оформлення власної норми, вважає Г. Щедровицький [9]. Особистісно-творчі шляхи формування рефлексії допомагають виявити певний центр управління потребами, можливість і необхідність вольового регулювання, виявляє свободу вибору. Науковець М. Мамардашвілі стверджує, що рефлексія - це «засіб самовизволення людини» [4].

Ми вважаємо, що спочатку треба змінити підходи до розроблення змісту й організації навчального процесу фундаментальних дисциплін, який має бути спрямованим на набуття не лише якісних знань, умінь і навичок із дисципліни, а й на формування професійної спрямованості, розвитку вмінь самостійної роботи, професійного творчого мислення у студентів. 
Отже, можемо зробити висновок про те, що теоретичний аналіз проблеми щодо визначення концептуальних основ формування рефлексивних умінь дозволяє окреслити основні вимоги до процесу їх формування: індивідуальний підхід до кожного студента; необхідність урізноманітнення поглядів студентів на свою самостійну навчальну діяльність; допускання суб'єктивності. Для ефективної рефлексії та формування рефлексивних умінь студентів необхідна цілеспрямована організація самостійної навчальної діяльності на науково обгрунтованій основі. Студентові необхідно мати можливість незалежно від інших стійко розуміти дії, робити висновки й на грунті їх аналізу перепрограмувати навчальну діяльність, у тому числі й самостійну навчальну діяльність.

\section{Література}

1. Болотов В. А. Проектирование профессионального педагогического образования / В. А. Болотов, Е. И. Исаев, В. И. Слободчиков, Н. А. Шайденко // Педагогика. - 1998. - № 4. С. 24. 2. Вачков И. В. Структура профессионального самосознания учителя / И. В. Вачков // Школьный психолог. - 2000. - №3.- С. 5 13. 3. Малихін О. В. Організація самостійної навчальної діяльності студентів вищих педагогічних навчальних закладів: теоретикометодологічний аспект : [монографія] / Олександр Володимирович Малихін. - Кривий Ріг : Видавничий дім, 2009. - 307 с. 4. Мамардашвили М. К. Формы и содержания мышления (к критике гегелевского учения о формах познания) / Мераб Константинович Мамардашвили. - М. : Высшая школа, 1968. - 214 с. 5. Маркова А. К. Педагогическая рефлексия как средство личностной самореализации будущих учителей в учебнопрофессиональной деятельности / А. К. Маркова // Наука и школа. - 1997. - № 4. - $\quad$ С. $22-23$. Методологическое обоснование рефлексивных методик / Валентина Александровна Метаева // Педагогика. - 2006. - № 7. - С. 38-44. 7. Разина Т. В. Рефлексия в решении педагогических проблемных ситуаций / Т. В. Разина // Ярославский психологический вестник. 2001. - № 5. - С. 21-25. 8. Решетников П. Е. Нетрадиционная технологическая система подготовки учителей. Рождение мастера / Петр Евдокимович Решетников. - М. : Владос, 2000. - 301 с. 9. Щедровицкий Г. П. Коммуникация, деятельность, рефлексия / Георгий Петрович Щедровицкий // Исследование речемыслительной деятельности. - Алма-Ата, 1974. - С. 12-28. 